\title{
ARCHIMEDES
}

\section{Towards evidence-based medicine for paediatricians}

\author{
Edited by Bob Phillips
}

Arch Dis Child 2007;92:266-273. doi: 10.1136/adc.2006.110080

$\mathrm{T}$ give the best care to patients and families, paediatricians need to integrate the highest quality scientific evidence with clinical expertise and the opinions of the family. ${ }^{1}$ Archimedes seeks to assist practising clinicians by providing "evidence-based" answers to common questions that are not at the forefront of research but are at the core of practice. In doing this, we are adapting a format that has been successfully developed by Kevin Mackway-Jones and the group at the Emergency Medicine Journal_- "BestBets".

A word of warning. The topic summaries are not systematic reviews, although they are as exhaustive as a practising clinician can produce. They make no attempt to statistically aggregate the data, nor to search the grey, unpublished literature. What Archimedes offers is practical, best evidencebased answers to practical, clinical questions.

The format of Archimedes may be familiar. A description of the clinical setting is followed by a structured clinical question. (These aid in focusing the mind, assisting searching ${ }^{2}$ and obtaining answers. ${ }^{3}$ ) A brief report of the search used follows - this has been performed in a hierarchical way, to search for the best quality evidence to answer the question (http://www.cebm.net). A table provides a summary of the evidence and key points of the critical appraisal. For further information on critical appraisal, and the measures of effect (such as the number needed to treat), books by Sackett ${ }^{4}$ and Moyer $^{5}$ may help. To pull the information together, a commentary is provided, but to make it all much more accessible, a box provides the clinical bottom lines.

Electronics-only topics that have been published on the BestBets site (www.bestbets.org) and may be of interest to paediatricians include the following.

- Can steroids be used to reduce post tonsillectomy pain?

Readers wishing to submit their own questions-with best evidence answers-are encouraged to review those already proposed at www.bestbets.org. If your question still hasn't been answered, feel free to submit your summary according to the instructions for authors at www.archdischild.com. Three topics are covered in this issue of the journal:

- Is teething the cause of minor ailments?

- Should steroid creams be used in cases of labial fusion?

- Does erythromycin cause pyloric stenosis?

Bob Phillips, Evidence-based On Call, Centre for Evidence-based Medicine, University Dept of Psychiatry, Warneford Hospital, Headington OX3 7JX, UK; bob.phillips@doctors.org.uk

\section{REFERENCES}

1 Moyer VA, Ellior EJ. Preface. In: Moyer VA, Ellioft EJ, Davis RL, et al, eds. Evidence based pediatrics and child health. Issue 1. London: BMJ Books, 2000.

2 Richardson WS, Wilson MC, Nishikawa J, et al. The well-built clinical question: a key to evidence-based decisions. ACP J Club 1995;123:A12-13.

3 Bergus GR, Randall CS, Sinift SD, et al. Does the structure of clinical questions affect the outcome of curbside consultations with specialty colleagues? Arch Fam Med 2000;9:541-7.

4 Sackett DL, Starus S, Richardson WS, et al. Evidence-based medicine. How to practice and teach EBM. San Diego: Harcourt-Brace, 2000.

5 Moyer VA, Elliott EJ, Davis RL, et al, eds. Evidence based pediatrics and child health. Issue 1. London: BMJ Books, 2000.

\section{Can: doing, using and replicating evidence- based child health}

The practice of evidence-based child health is said to be the five-step way of asking questions, acquiring information, appraising the evidence, applying the results and assessing our performance.

If the truth be known, for the vast majority of the time, most of us perform our clinical practice replicating what we have done previously. Most of the time this is based on the combination of excellent education, skilled interpretation of clinical findings, and good discussions with children and families. We hope that the education we rely on was (and remains) based on the best available scientific evidence. If it is, we are practising a form of "micro-evidence-based healthcare (EBHC)" (doing just step 4).

Sometimes, we question our knowledge (or more uncomfortably, someone does this for us), and will head off to top up our understanding of an area. This "using" mode, if we use wellappraised resources to supply our thirst for information, will also promote the practice of evidence-based care. This midiEBHC asks us to go through steps 1, 2 and 4 .

Occasionally, we also actually need to go through the entire process of getting "down and dirty" with the primary research and appraising it to influence our practice. Maxi-EBHC is considerably more demanding in time, but largely more satisfying intellectually.

If we reframe the practice of $\mathrm{EBHC}$ as using the family and child values, the best evidence, and our clinical expertise, then we can do it by micro-methods, midi-methods or maximethods, and choose the most appropriate approach for the situation we confront.

\section{Acknowledgement}

I thank Dr Sharon Straus, Director of the Center for Evidencebased Medicine, University of Toronto, Toronto, Ontario, Canada.

\section{Does a teething child need serious illness excluding?}

\author{
Report by \\ M Tighe, St Mary's Hospital, Portsmouth, UK; \\ mpt195@hotmail.com \\ M F E Roe, Southampton General Hospital, \\ Portsmouth, UK
} doi: 10.1136/adc.2006.110114 n 8-month-old girl has been referred to the emergency department by her general practitioner with a 24-h history of drooling, intermittent screaming and 
Table 1 Studies examining the link between teething and systemic symptoms

\begin{tabular}{|c|c|c|c|c|c|}
\hline Authors & Study group & Study type & Methods & Key outcomes & Comments \\
\hline $\begin{array}{l}\text { Wake et al } \\
\text { (Australia) }\end{array}$ & $\begin{array}{l}21 \text { children from } 3 \\
\text { day-care nurseries } \\
\text { assessed over } \\
2067 \text { days. } 90 \\
\text { teeth erupted } \\
\text { during the study } \\
\text { period }\end{array}$ & $\begin{array}{l}\text { Level } 1 \mathrm{~b}: \\
\text { prospective } \\
\text { cohort study with } \\
\text { objective } \\
\text { assessment }\end{array}$ & $\begin{array}{l}\text { Daily assessment for } \\
7 \text { months by independent } \\
\text { practitioner, including } \\
\text { temperature and gum } \\
\text { examination with daily } \\
\text { symptom questionnaire } \\
\text { recorded independently by } \\
\text { parents and staff }\end{array}$ & $\begin{array}{l}\text { No association between teething and fever, } \\
\text { mood disturbance, appearance of illness, } \\
\text { sleep disturbance, drooling, diarrhoea, } \\
\text { strong urine, red cheeks, or rashes/flushing } \\
\text { on the face or body. Parental data } \\
\text { suggested an association between loose } \\
\text { stools and teething, but this was not seen } \\
\text { in data from assessing staff }\end{array}$ & $\begin{array}{l}\text { 78\% enrolment rate. } \\
6 \% \text { of dental therapist and } \\
13 \% \text { of day-care staff data } \\
\text { not available.Mean age of } \\
\text { children enrolled } \\
=14.4 \text { months. This is the } \\
\text { only study with an } \\
\text { objective assessment of } \\
\text { teething and a clear } \\
\text { definition of teething. No } \\
\text { description of statistical } \\
\text { method, but logistical } \\
\text { regression used in results }\end{array}$ \\
\hline $\begin{array}{l}\text { Macknin et aR } \\
\text { (Cleveland, } \\
\text { USA) }\end{array}$ & $\begin{array}{l}125 \text { infants } \\
\text { enrolled at } \\
4 \text { months assessed } \\
\text { over } 19422 \text { days. } \\
475 \text { teeth erupted } \\
\text { during study period }\end{array}$ & $\begin{array}{l}\text { Level } 2 \mathrm{~b} \text { : } \\
\text { prospective } \\
\text { cohort study } \\
\text { with parental } \\
\text { assessment }\end{array}$ & $\begin{array}{l}\text { Twice-daily assessment for } \\
8 \text { months by parents, } \\
\text { including temperature and } \\
\text { gum examination with daily } \\
\text { symptom questionnaire } \\
\text { recorded by parents }\end{array}$ & $\begin{array}{l}\text { Symptoms significantly associated with } \\
\text { teething: increased biting, drooling, facial } \\
\text { rash, irritability and fever (all }<38.3^{\circ} \mathrm{C} \text { ). } \\
\text { No symptom occurred in }>35 \% \text { of infants } \\
\text { during the teething period; no symptom } \\
\text { occurred in }>20 \% \text { more often in the } \\
\text { teething period than in the non-teething } \\
\text { period. No symptom reliably predicts } \\
\text { teething. Diarrhoea/cough/vomiting/fever } \\
>38.9^{\circ} \mathrm{C} \text { not associated. No serious } \\
\text { illnesses }\end{array}$ & $\begin{array}{l}25 \% \text { enrolment rate - } \\
\text { presumably only highly } \\
\text { motivated families } \\
14(>10 \%) \text { of families } \\
\text { enrolled provided no } \\
\text { information. No objective } \\
\text { assessment of tooth } \\
\text { eruption. } \\
\text { Power study and } \\
\text { appropriate statistical } \\
\text { method presented. }\end{array}$ \\
\hline $\begin{array}{l}\text { Jaber et a }{ }^{\beta} \\
\text { (Israel) }\end{array}$ & $\begin{array}{l}46 \text { infants enrolled } \\
\text { prior to first tooth } \\
\text { eruption }\end{array}$ & $\begin{array}{l}\text { Level } 2 \mathrm{~b} \text { : } \\
\text { prospective } \\
\text { cohort study } \\
\text { with parental } \\
\text { assessment }\end{array}$ & $\begin{array}{l}\text { Daily assessment by parents, } \\
\text { including temperature and } \\
\text { gum examination with daily } \\
\text { symptom questionnaire } \\
\text { recorded by parents } \\
\text { Presentation with tooth } \\
\text { eruption confirmed objectively } \\
\text { Data from } 20 \text { days preceding } \\
\text { tooth eruption used for } \\
\text { analysis }\end{array}$ & $\begin{array}{l}\text { Significant difference in temperature, } \\
\text { using } 37.5^{\circ} \mathrm{C} \text { as a cut-off value, was } \\
\text { found between day of tooth eruption } \\
\text { and preceding days }\left(\chi^{2} \text { test } p<0.025\right)\end{array}$ & $\begin{array}{l}\text { Parents blinded as to } \\
\text { reason for daily symptom } \\
\text { recording, but asked to } \\
\text { present child when tooth } \\
\text { eruption suspected. } \\
\text { No discussion of } \\
\text { prevalence of other } \\
\text { symptoms } \\
\text { Temperature data } \\
\text { analysed with } \\
\text { discontinuous statistics }\end{array}$ \\
\hline $\begin{array}{l}\text { Peretz et al }{ }^{4} \\
\text { (Colombia) }\end{array}$ & $\begin{array}{l}585 \text { children } \\
\text { assessed at clinic } \\
\text { (145 infants with } \\
\text { erupting teeth, } \\
357 \text { controls) }\end{array}$ & $\begin{array}{l}\text { Level } 3 \mathrm{~b} \text { : } \\
\text { retrospective } \\
\text {-case control } \\
\text { study }\end{array}$ & $\begin{array}{l}\text { Single clinical assessment of } \\
\text { tooth eruption. Retrospective } \\
\text { questionnaire completed by } \\
\text { parents }\end{array}$ & $\begin{array}{l}40 \% \text { of teething children were } \\
\text { asymptomatic. } 93 \% \text { of control children } \\
\text { were asymptomatic. } \\
60 \% \text { of children had at least one of the } \\
\text { following symptoms reported: drooling } \\
(32 \%) \text {, fever }>39^{\circ} \mathrm{C}(25 \%) \text {, diarrhoea } \\
(35 \%) \text { Presence of drooling and fever } \\
\text { were assessed at clinic visit }\end{array}$ & $\begin{array}{l}\text { No comparison of study } \\
\text { and control groupsData } \\
\text { not presented on } 83 \\
\text { children in control group } \\
(19 \%) \text {. No distinction } \\
\text { between objective and } \\
\text { reported symptoms. } \\
\text { Temperature cut-off of } \\
>39^{\circ} \mathrm{C} \text { used and analysed } \\
\text { with discontinuous statistics }\end{array}$ \\
\hline $\begin{array}{l}\text { Cunha et } a l^{5} \\
\text { (Brazil) }\end{array}$ & $\begin{array}{l}\text { Records of } 1813 \\
\text { children aged } 0- \\
3 \text { years seen at } \\
\text { dental baby clinic }\end{array}$ & $\begin{array}{l}\text { Level } 4 \text { : } \\
\text { retrospective } \\
\text { case series }\end{array}$ & $\begin{array}{l}\text { Case note analysis for } \\
\text { specific symptoms associated } \\
\text { with tooth eruption }\end{array}$ & $\begin{array}{l}1165 \text { records ( } 64 \% \text { ) had sufficient } \\
\text { information. } 95 \% \text { of children had some } \\
\text { symptoms associated with tooth eruption, } \\
\text { but these included gingival itching and } \\
\text { irritation }\end{array}$ & $\begin{array}{l}\text { No control patients. No } \\
\text { definitions of symptoms or } \\
\text { signs. No ability to } \\
\text { determine whether any } \\
\text { results were significant }\end{array}$ \\
\hline
\end{tabular}

low-grade fever (maximum $38.2^{\circ} \mathrm{C}$ ). She is refusing solids and her fluid intake has decreased. Her parents report that her nappies are drier than normal but her stools are looser. She has had some relief from oral paracetamol syrup. Her parents suspect teething.

On examination she is found to be miserable. She is not clinically dehydrated and has a diffusely hyperaemic right cheek. On examination of her mouth you notice a raw area on her upper gums where two teeth are erupting. No other abnormal clinical signs are noted.

You agree that the infant may be teething, but wonder if there are any symptoms that would distinguish between teething and an alternative diagnosis.

In an infant with suspected teething (patient), are there any symptoms or signs pathognomonic of teething (assessment) that would allow for the reassurance of parents without further management (outcome)?

Secondary sources: none.

Medline (1966-September 2006) using the Ovid interface was analysed for articles containing the keywords "(teething or tooth) and symptom\$ and (infant or baby)". Limits included human and English language only.

In total, 78 articles were identified, of which teething was the main focus in 21 articles. There were three prospective studies ${ }^{1-}$ ${ }^{3}$ and two retrospective studies ${ }^{4}{ }^{5}$ examining the link between teething and systemic symptoms in the community (table 1 ). These form the basis of our evidence-based review. Another retrospective review presented the diagnoses of 50 children admitted to hospital with a presenting complaint of teething. ${ }^{6}$ This is discussed separately.

One previous letter commented on the three prospective trials. ${ }^{7}$ Nine articles found were questionnaire studies on beliefs of local populations (both health professional and parental) regarding teething. Studies not discussed here include cytokine levels in the gingival area $(n=1)$, effects of mercury exposure on teething $(n=1)$, misuse of teething gel $(n=1)$, herpes stomatitis mimicking teething $(\mathrm{n}=1)$, and a nursing article on teething that was purely descriptive. One article summarised the study by Wake et $a l^{8}$ and is also not discussed. 


\section{Commentary}

From this review, it is apparent that a number of children develop symptoms that their parents/carers attribute to teething. However, although our analysis shows that a variety of symptoms may occur contemporaneously with teething, there is no pattern of symptoms manifesting in all the studies that can reliably distinguish teething from any other potential cause of the symptoms. The most robust study by Wake et al ${ }^{1}$ did not confirm any notable association between teething and systemic symptoms. However, the mean age of the children enrolled was 14.4 months, which is older than that in other studies. The mean age of eruption of the first tooth, usually a lower incisor, is around 8 months and so this study may have missed the majority of first-tooth episodes. Peretz et $a l^{4}$ did analyse symptoms with respect to age, and although the data are retrospective their results suggest that teething symptoms peak around 12-15 months.

The largest study by Macknin et $a^{2}$ showed significant $(\mathrm{p}<0.01)$ associations with biting, drooling, gum rubbing, irritability, sucking and temperature $>37.5^{\circ} \mathrm{C}$. However, attributing these symptoms to teething was not possible as no symptom occurred in $>35 \%$ of infants during each teething period, and no symptom occurred $>20 \%$ more often in the teething period than in the non-teething period.

The results presented by Jaber et $a l^{3}$ considered only temperature and only included children before the emergence of their first tooth. This was despite a daily record kept by the parents of a number of other symptoms, including diarrhoea. The data presented in graph form suggest that there is an increase in temperature at the time of the first tooth eruption, and the $95 \%$ confidence intervals $\left(37.33^{\circ} \mathrm{C}\right.$ to $\left.37.86^{\circ} \mathrm{C}\right)$ exceeded the mean temperatures on days before the tooth eruption $\left(\leqslant 37.1^{\circ} \mathrm{C}\right)$. However, there are no confidence intervals for the mean temperatures before the eruption, and it is not possible to determine the relevance of these data.

The conclusions of all the prospective studies are that no specific symptoms or clusters of symptoms can reliably predict the emergence of a tooth. Furthermore, symptoms that might be attributed to teething are not serious, and the presence of fever $\left(>38.5^{\circ} \mathrm{C}\right)$ or other clinically important symptoms are very unlikely to be caused by teething. This is borne out by Swann, ${ }^{6}$ who reviewed 50 children admitted to hospital with a presenting complaint of teething. In 48 children, a medical condition was diagnosed, including one case of bacterial meningitis.

Nine studies assessed perceptions in certain populations from countries including Nigeria, ${ }^{9-11}$ Australia, ${ }^{12}{ }^{13}$ Turkey, $^{14}$ the USA, ${ }^{15}$ Israel $^{16}$ and Guinea-Bissau. ${ }^{17}$ These studies are subjective and open to recall bias and hence are not included in the evidence base of this report. However, they do demonstrate the widely held secular view that teething can cause many clinical symptoms-for example, in the Guinea-Bissau population, only 33\% of parents with "severely dehydrated" children would seek medical help if they thought that the dehydration was secondary to teething. On the other hand, teething may be a label for minor ailments and provide a rationale that parents can accept. This label may also provide confidence to the carers of children that the child can be managed without resorting to formal healthcare. ${ }^{1}$

Our critical appraisal found two large well-designed studies that show that teething is unlikely to be associated with relevant clinical symptoms and signs, and one smaller study which showed a possible association between temperature and the eruption of the first tooth. The two large retrospective studies were not sufficiently robust to provide further information. We also identified one paper highlighting the risks of attributing relevant medical symptoms to teething

This review suggests that there is no evidence that teething can be "identified" as the source of symptoms in a child. We agree with previous authors and recommend that this is a diagnosis of exclusion, to be made with caution. We acknowledge that this message may conflict with many firmly held beliefs of our patients' parents and of other colleagues, but this review has shown that if a child is ill enough to be admitted to hospital, other organic causes need to be excluded, so that the child is managed appropriately. We also suggest that visualisation of the gums should be part of the clinical examination of the mouth and pharynx in young children to deal with the possible parental concerns, as teething has often been diagnosed on the basis of symptoms alone.

\section{CLINICAL BOTTOM LINE}

No evidence is available to suggest that there are any symptoms or signs specific to teething that allow a diagnosis to be made confidently in a child without excluding other organic pathology (grade B).

\section{REFERENCES}

1 Wake $M$, Hesketh $K$, Lucas J. Teething and tooth eruption in infants: a cohort study. Pediatrics 2000;106:1374-8.

2 Macknin ML, Piedmonte M, Jacobs J, et al. Symptoms associated with infant teething: a prospective study. Pediatrics 2000;104:747-52.

3 Jaber L, Cohen IJ, Mor A. Fever associated with teething. Arch Dis Child 1991;67:233-4.

4 Peretz B, Ram D, Hermida L, et al. Systemic manifestations during eruption of primary teeth in infants. J Dent Child 2003;70:170-3

5 Cunha RF, Pugliesi DM, Garcia LD, et al. Systemic and local teething disturbances: prevalence in a clinic for infants. J Dent Child 2004;71:24-6.

6 Swann IL. Teething complications, a persisting misconception. Postgrad Med $J$ 1979;55:24-5

7 South M. On teething symptoms. BMJ 2003;326:282

8 Frank J, Drezner J. Is teething in infants associated with fever or other symptoms? J Fam Pract 2001;50:257.

9 Bankole OO, Denloye OO, Aderinokun GA. Attitude, beliefs and practices of some Nigerian nurses toward teething in infants. Odontostomatol Trop 2004;27:22-6.

10 Oyejide CO, Aderinokun GA. Teething myths in Nigerian rural Yoruba communities. Afr Dent J 1991;5:31-4.

11 Denloye O, Bankole OO, Aderinokun GA. Teething myths among community health officers. Odontostomatol Trop 2005;28:19-22.

12 Wake M, Hesketh K, Allen M. Parent beliefs about infant teething: a survey of Australian parents. J Paediatr Child Health 1999;35:446-9.

13 Wake $M$, Hesketh $K$. Teething symptoms: cross sectional survey of five groups of child health professionals. BMJ 2002;325:814.

14 Baykan Z, Sahin F, Bayazova U, et al. Experience of Turkish parents about their infants teething. Child Care Health Dev 2004;30;331-6.

15 Barlow BS, Kanellis MJ, Slayton RL. Tooth eruption symptoms; a survey of parents and health professionals. J Dent Child 2002;69:148-50, 123-4.

16 Sarrell EM, Horev Z, Cohen Z, et al. Parents and medical personnel's beliefs about infant teething. Patient Educ Couns 2005;57:122-5.

17 Sodemann M, Jakobsen MS, Molbak K, et al. Management of childhood diarrhoea and use of oral rehydration salts in a suburban West African community. Am J Trop Med Hyg 1999;60:167-71.

\section{Is the topical application of oestrogen cream an effective intervention in girls suffering from labial adhesions?}

\author{
Report by \\ Marc Tebruegge, Department of Paediatrics, \\ Southend University Hospital, Southend-on-Sea, UK; \\ marctebruegge@nhs.net \\ Indranil Misra, Veerasingam Nerminathan, \\ Department of Paediatrics, Southend University \\ Hospital, Southend-on-Sea, UK \\ doi: 10.1136/adc.2006.110528
}

A 4-year-old girl presents with low-grade pyrexia and dysuria. A urine dipstick test shows positive results for leucocytes and nitrite, suggesting urinary tract infection. 